\title{
The Implications of Centre-local Relations on Service Delivery in Local Authorities in Zimbabwe: The Case of Chitungwiza
}

\author{
Tawanda Nyikadzino \\ University of Zimbabwe, Department of Political and Administrative Studies
}

Harare Zimbabwe

Alfred G. Nhema

University of Zimbabwe, Department of Political and Administrative Studies

Harare, Zimbabwe

Doi:10.5296/ jpag.v5i2.7751 URL: http://dx.doi.org/10.5296/ jpag.v5i2.7751

\begin{abstract}
The area of centre-local relations in local government is a contemporary and topical debate in Zimbabwe. It was on this background that the research on centre-local relations was undertaken with a view to assessing the implications of service delivery in Chitungwiza Municipality $(\mathrm{CM})$. The views of different authorities on centre-local relations were reviewed to further analyse the implications of centre-local relations on service delivery in municipalities. The study triangulated different data collection methods such as key informant interviews, documentary search, in-depth interviews, observation and survey to obtain detailed data on the state of centre-local relations and its implications on service delivery in CM. The findings of the study revealed that centre-local relations between the Ministry of Local Government and the CM are highly centralised. The parent ministry retains overall powers and control over the municipality. The Minister who is supposed to play a strategic role in policy formulation and implementation is involved in the day to day running of the municipality leaving little room for elected councillors and residents in general to determine their own destiny. It has been established that centre-local relations that are supposed to foster independence and autonomy of the municipality has turned into a master-subordinate relationship that has negatively affected service delivery. The study concluded that hyper-centralised governance relations are hindering effective service delivery in the municipality. This has been evidenced by erratic water supply, potholed roads, poor
\end{abstract}


refuse collection and bursting of sewer pipes. The study recommends that the central government through the Ministry of Local Government must grant the municipality more autonomy as a measure of improving service delivery.

Keywords: Measurement, Fear of Crime, Limitations, Advancements, Validity, Reliability

\section{Introduction}

The article assesses the implications of centre-local relations on service delivery in local authorities in the context of Zimbabwe though a study of the case of Chitungwiza Municipality (CM). The municipality, created in 1978, is a high density town that is about 30 kilometres south of the capital, Harare comprising of three townships of Seke, Zengeza, and St Marys. The main objective is to ascertain the nature of interactions between the central government through the Ministry of Local Government, Public Works and National Housing (MLGPWNH) and local authorities utilizing the case study of Chitungwiza Municipality (CM) with a view to assess how that impacts on service delivery. Generally, centre-local relations refer to the interaction (political, administrative and financial) between central governments and local authorities with a specific country. Bevir (2009:44) defines centre-local relations as the political and administrative relationships that exist between a central state and the local governments within its territorial boarders. Local authorities on the hand are decentralised lower tiers of government which are closer to the people under the control of locally elected councillors. It is the argument of this article that the relationship between the MLGPWNH and CM is hyper-centralised and in the process hindering effective service delivery. The MLGPWNH is interfering in the management of the municipality through directives, appointment of key officials and firing of elected councillors in the process jeopardising service delivery. This has been evidenced by erratic water supply, undesignated dumping sites, potholed roads and bursting sewer pipes.

\section{Historical Background of Centre-local Relations in Zimbabwe}

The study of centre-local relations in Zimbabwe can be traced back to the colonial era. Zimbabwe was colonised by the British South African Company (BSAC) which settled in the country in 1890 and introduced western type of local government management which was mainly dominated by the settler white the ruling elites (Nhema, 2002). The local government model introduced was highly centralized and dominated by the colonialists. Major policies and important decisions on local government issues such as land distribution and other services were mainly introduced by the ruling elites without any meaningful participation of the local residents especially in those localities dominated by the blacks.

Zhou and Madhekeni (2012:20) have noted that there was demonstration of central government supremacy in municipalities through ingrained draconian and tribal legal and institutional framework which resulted in strong conflict and opposition by the blacks through the liberation fight. They further postulate that various legislations for instance the Ordinance 2 were enacted to further entrench the expropriation of African lands. Jordan (1983) argues that the legislation facilitated the imposition of child-like and centrally defined 
programmes such that any intention to promote local government autonomy was thwarted by white supremacist policies. Native Councils covering communal farming lands were subjected to central control and district commissioners in these areas were appointed by the central government (Helmsing et al 1994). Generally, centre-local relations in the colonial era were dominated by the central government with local authorities playing a subservient role. It was more of a master-servant relationship.

At independence, the government introduced aggressive strategies to counter the domination of the whites in local government business. The new structures and the expanded decentralization of local government structures and configurations were deliberately designed to cater for the majority of the people that had been disenfranchised before independence in 1980. In the process, the new thrust sowed the seeds for ministerial intervention and control over local authorities. After independence, the government invariably made efforts to remove the racial connotations imbedded in the laws and practice of local government (The Economic Consulting Associates (ECA) (2011), Makumbe (1998). This has been done largely through giving more powers to the Minister to be able to intervene appropriately on behalf of the disadvantaged African populations in urban areas.

Hemsing (1995) further notes that at independence (1980) the government of Zimbabwe amalgamated African councils into District Councils thereby establishing new legislations that are the Urban Councils Act (UCA) and the Rural District Councils Act (RDCA). A single ministry of local government was also created. However, the new setup did not completely hinder the central government from meddling in local government businesses. The UCA (chapter 29:15) gave the Minister of Local Government too much freedom and unlimited powers to interfere in the affairs of local authorities.

\section{Theoretical Framework}

\subsection{Principal-agent Theory}

The study was guided by the principal-agent theory. Waterman and Meier (1998) illustrate that the theory is derived from disciplines such as law, finance, accounting and economics and it has become the basis for an extensive set of studies relating bureaucracy to elected officials. According to Meckling (1976:308), an agency relationship is a contract under which one or more persons (the principal(s) employ someone (agent) to execute certain tasks on their behalf. Waterman and Meier (1998:174) argue that the theory makes two assumptions that goal conflict exist between principals and agents and that agents have more information than their principal which results in an information asymmetry between them. The theory assumes that the principal-agent relationship will be characterised by a conflict between the interests of the principal and those of the agent and that the agent will be motivated to pursue his or her own goals (Caers 2006). The theory also assumes that the agent is not keen on taking risk (the agent is risk averse) and the principal on the other hand is risk neutral (ibid). When the agent's behaviour is not controlled or restrained the goals of the principal are unlikely to be attained. Implied is that the principal must monitor the behaviour of the principal. 
With reference to this study, the general public or residence are the principal with the municipality acting as an agent. Residence in this case expect local governments to provide them with public goods and services such as water, refuse collection, health, education, fire protection and houses to mention but a few. However, because residence lacks the monitoring capacity to closely monitor the behaviour of the agent (local government), they assigned the central government through the Ministry of Local Government to monitor the activities of local authorities on their behalf. Information asymmetry exists between the two spheres of government with the municipality possessing more information. This results in the local authority pursuing its self interests at the expense of the public interests and this lead to a principal-agent problem.

Caers (2006:26) argues that to counteract the agency conflict the theory recommends that certain measures must be put in place to help the principal to control the behaviour of the agent and align the interests of the agent with those of the principal. The theory as argued by Coletta (2013) recommends that the principal must construct incentive contracts to measure and compensate the performance of the agent. According to Caers (2006) there must be performance management in place for the principal to be in a position to monitor the behaviour of the agent. Waterman and Meier (1998:177) argue that after managing performance when the agent's behaviour stray from the principal's preferences, the principal can apply sanctions or rewards to bring agents back into line.

\section{Major Findings}

\subsection{Centre-local Relations in Chitungwiza}

Findings from the study established that the relationship between the MLGPWNH and the $\mathrm{CM}$ is highly centralised. The study revealed that the balance of power is highly tilted in favour of the MLGPWNH which plays an active role in the running of the CM. Concerning the clarity of the relationship one councillor in the CM has this to say:

The minister has a tendency of controlling in detail the activities undertaken by the municipality. $\mathrm{He}$ is controlling the operations of the municipality using a remote control through the appointment of commissions and special interest councillors who are disturbing our responsibilities as representatives of the people.

The Minister has a tendency of controlling in detail the activities undertaken by the municipality. This concurs with the view of Chipangura (2014:11) who argues that the Minister cannot simply leave local authorities to run their business. This is also in agreement with Golola (2003) who states that politicians at the centre have little wish to cede power to the local government. Centralisation of power is not peculiar to Zimbabwe. It is also bedevilling service delivery in other African countries. Olowu (2009:4) postulates that the major challenge facing decentralisation in Africa is that the national leaders fear that the transfer of power to local levels represents a zero-sum game in which local leaders (who might be politicians in a different party) gain power and resources at their expense. The figure below shows the level of ministerial influence in CM. 
Figure 4.1: Level of Ministerial Interference

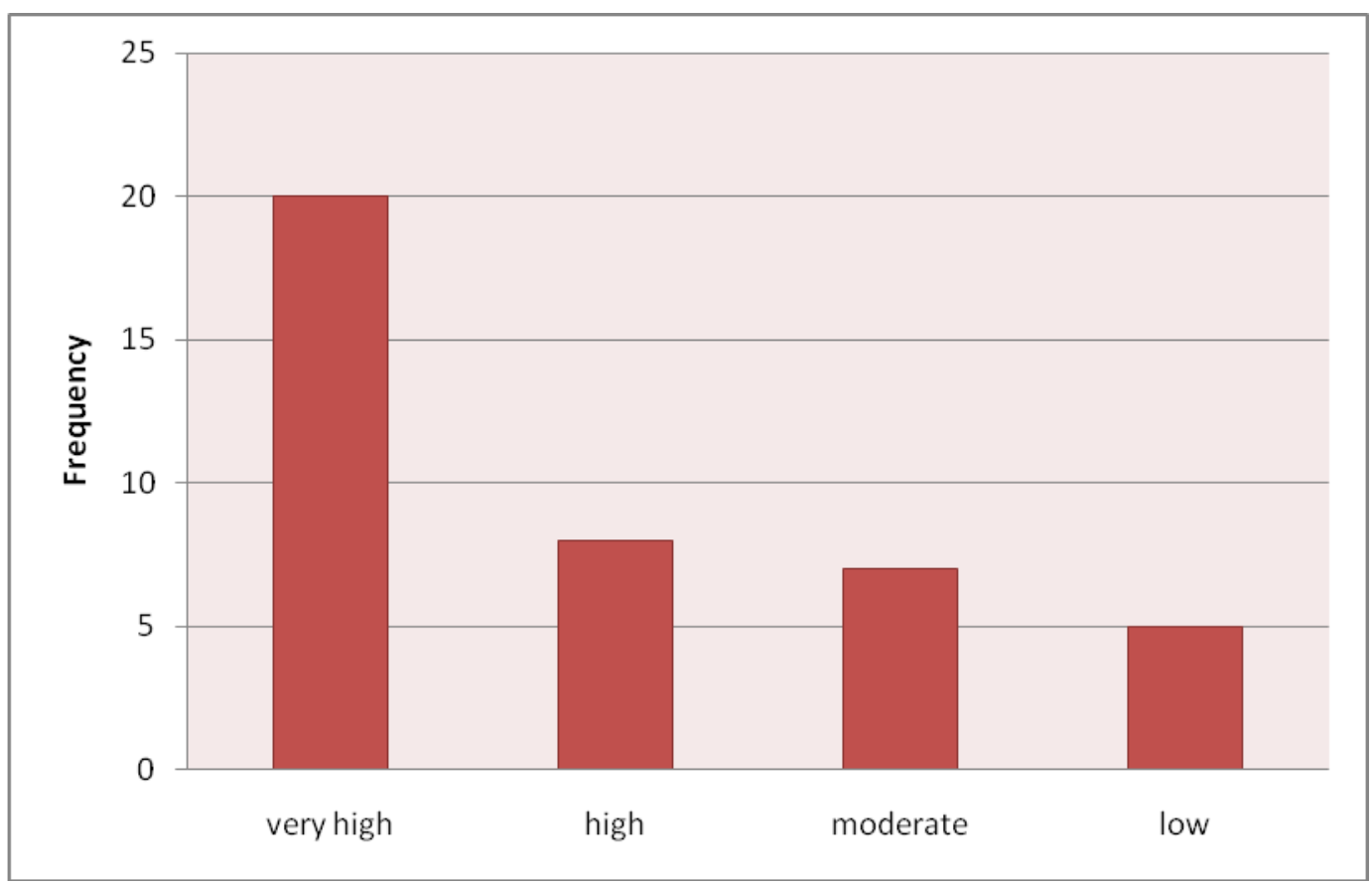

The above diagram shows that $62.5 \%$ of the respondents strongly agreed that ministerial interference contributed to poor service delivery and $17.5 \%$ agreed. The cumulative percentage of those who agreed that ministerial interference contributed to the decline of service delivery in Chitungwiza stands at $80.0 \%$. This illustrates that there is high ministerial interference in $\mathrm{CM}$ which is jeopardising service delivery.

The Minister who is supposed to play a strategic role in policy formulation and implementation is involved in the day to day running of the municipality leaving little room for elected councillors and residents in general to determine their own destiny. The Ministry has also been involved in routine decision making which in actual fact is a responsibility of the municipality. According to Madzivanyika (2011:33) efficient and effective provision of goods and services is compromised by a high level of central interference in the decision-making processes of local authorities. Findings indicated that the centre-local relationship that is suppose to foster independence and autonomy of the municipality in the provision of goods and services has turned into a master-servant relationship that has negatively affected service delivery in CM.

The MLGPWNH controls most important financial activities of the municipality for instance budgeting, borrowing and the billing system. This scenario is similar to that in Britain. Chandler (1993:21) argues that in Britain the central government has a number of ways of either paying the pipes or exercising a considerable degree of control over the income of local authorities through regulation of the central grant system, influence over local government pricing policies and most importantly attempt to restrict the money that can be raised from the hitherto sacrosanct source of local taxation. Key informants in the department of finance noted that the central government through the MLGPWNH provide funds to the municipality 
under the Public Sector Investment Programme (PSIP) although there is a marked decrease in the amount of money provided due to economic hardships which saw the central government failing to fund local authorities.

Key informant interviews with an official in the department of finance also revealed that the MLGPWNH approves the budget of the municipality to ensure that the needs of the residents are prioritised in the budget. This is in agreement with the view of Marumahoko (2011:52) who opined that consistent with the national best practice, the MLGPWNH also ensures compliance to the $30 \%$ to $70 \%$ wage service ratio. This provides mechanisms for monitoring the budget of the municipality making sure that $70 \%$ of the budget is used for service delivery such as refuse collection, sewerage maintenance, water supply, road maintenance and health service provision (ibid). This prevents council officials from awarding themselves unjustified salaries. However, in the case of the CM the opposite is true because $70 \%$ of the revenue in gobbled by the wage bill.

Officials in the MLGPWNH and those in the municipality generally agreed that the central government through the MLGPWNH controls the billing policy of local authorities in Zimbabwe. This was also echoed by Murumahoko (2011:49) who revealed that the ability of local authorities to mobilise revenue is compromised by the UCA which compels them to seek ministerial approval for tariffs imposed. The Act also forces local governments to seek ministerial approval imposing any tariff.

Key informants in the District Administrator's office were of the view that the objective of such a billing policy is to ensure that the poor are not marginalised from municipal goods and services because of their incapacity to pay for the services rendered. In this case, the central government will be trying to take into account the problems of the unfortunate and create equality in society. Therefore, administrative controls exerted on the municipality by the MLGPWNH are quite extensive especially in financial terms. Centralisation of financial powers further entrenches the subordinate role of the municipality in that the revenue powers, expending and borrowing powers are being validated by the ministry.

Top officials in CM were of the view that the parent ministry retains overall powers and control over the municipality. Over the years the municipality continued to depend heavily on the MLGPWNH for most of its operations and general sustenance rather than becoming a relatively autonomous organisation. Central government domination in the affairs of municipalities is not peculiar to Zimbabwe. Dipholo and Gumede (2013:1) illustrate that in Botswana local authorities are simply an extension of the central government responsible for the implementation of central government policies at lower levels. They added that the nature of centre-local relations in Botswana subject local authorities to torturous control by the central government in a way that significantly compromise service delivery and local autonomy. Centre-local relations between the MLGPWNH and CM mean that the later is more or less an extension of the former responsible for the implementation of ministerial directive at the lower level of government. This shows that centre-local relations between the two spheres of government are highly centralised with the MLGPWNH having supreme powers over the management of the CM. Resultantly, the municipality has been reduced to 
a mere implementing agent of the ministry and has been left vulnerable to torturous control by the parent ministry in a manner that greatly undermines its operational autonomy and service delivery in general.

\subsection{Implications of Centre-Local Relations on Service Delivery}

\subsubsection{Negative Implications}

\section{Effects of Ministerial Directives on Council Operations}

The study revealed that centre-local relations are to a greater extent responsible for the deterioration of service delivery in CM. Key informants (council officials) cited ministerial directives as an important weapon at the disposal of the MLGPWNH to meddle in the affairs of the municipality to the detriment of service delivery. Jonga and Chirisa (2009) argue that directives traded good governance for political advantage and because of this the MLGPWNH therefore came heavily on urban councils thereby thwarting any remaining elements of freedom, good governance, commitment and initiative amongst councillors and council employees. For instance, in 2006 the MLGPWNH directed Zimbabwe National Water Authority (ZINWA) to take over the management of water and sewer from local authorities citing their incapacity to provide these services. However, documentary search revealed that when the management of water and sewer was under ZINWA there were no significant improvements in the service delivery situation (Mushamba (2010), Jonga and Chirisa (2009)). They further argue that in the period between 2000 and 2008 the water delivery situation worsened. This was evidenced by erratic water supply and constant bursting of main pipes. Officials in the department of finance argue that the transfer of water management to ZINWA greatly affected revenue inflows. This was supported by Mushamba (2010:109) who postulates that local authorities viewed this as a planned move to deprive them of their traditional source of revenue. Therefore, hyper-centralised centre-local relations hinder effective service delivery.

In addition, the taskforce or resuscitation teams and investigation teams from the MLGPWNH are sucking out the much needed cash for service delivery from the municipality. This greatly undermines effective service delivery since money is regarded as the oil of administration. This was supported by Sibanda (2013) who revealed that the MLGPWNH directed the CM to pay $\$ 300000$ in allowances to the 16 member commission which was set to investigate the issue of illegal structures in Chitungwiza. One key informant in the department of finance notes that each member of the team was pocketing $\$ 900$ a day meaning that by the end of the 20 days investigation each got a total of $\$ 15000$, they also received $\$ 4600$ to share amongst themselves and they were given a full tank of petrol every morning (Matenga 2013). In 2012 the Minister also set a resuscitation team which was led by Mbetsa. Chipangura (2014:11) notes that the team instead of resuscitating service delivery in CM was itself milking the municipality of thousands of dollars in obscene allowances. It was unearthed that the leader of the team was getting a total of \$26 525 salary per month, his deputy was paid $\$ 14500$ and the other five members got $\$ 13500$ each. The leader of the team's excuse on these high allowances was that, "The fees were fixed by the Minister of Local Government for a team of professionals who are not volunteers..." (Ibid). The 
MLGPWNH directed the bleeding municipality to meet the hefty allowances. This scenario greatly affected service delivery since the money eye marked for service delivery was diverted to meet the allowances of the teams set by the Minister.

The directives were issued at a time when the municipality was struggling to pay employees their ten month salary arrears and provide services. Members of the Chitungwiza Residents Trust (CRT) criticised the Minister for being insensitive to the problems of the municipality and the residents in general. The Chitungwiza mayor was surprised by these high allowances which were incurred at a time when the municipality was operating in an environment of limited fiscal space. A key informant in the department of finance postulates that the major problem with ministerial directives is that they are not followed with funding. This has been worsened by the fact that the central government in no longer providing fiscal transfers to local authorities. As a result, the cash-strapped municipality was forced to meet the expenses of such directives at the expense of service delivery. Such a scenario resulted in services such as waste management and water provision and sanitation grinding to a halt. Thus the relationship between the $\mathrm{CM}$ and the parent ministry is detrimental to service delivery as it has resulted in misuse of ratepayers' money.

Furthermore, the MLGPWNH directed the municipality in 2013 to cancel all debts owed by residents. The cancellation of debts became a highly contestable arena mainly because various stand points emerged from diverse constituencies in trying to explain its implications on service delivery. Residents appreciated the initiative but however the cancelation put a serious financial strain on council operations. The directive created shortages of council finances. An official in the department of finance described the directive as an unfortunate move that resulted in the dwindling of revenue in an already fiscally constrained municipality. The situation was worsened by the fact the government has no plans to financial support the municipality. This view was supported by Tafirenyika (2013) who revealed that in the aftermath of debts write-off revenue inflows in the municipality plummeted with council collecting an average of $\$ 7000$ per day compared to the usual $\$ 50000$. Salary problems in the municipality persisted with employees going for more than ten months without pay. This led to employee dissatisfaction resulting in poor service delivery. The municipality was not given a chance to be heard before the decision to cancel debts was reached.

\section{Loss of Fiscal Autonomy}

Madzivanyika (2011:33) alleges that efficient and effective provision of services is undermined by a high level of central interference in the decisions of municipalities. The UCA empowers the Minister to approve budgets of local authorities and the Minister is also in control of the billing system by the municipality. Madzivanyika (2011:35) revealed that the design of the UCA limits the capacity of urban councils to raise taxes or tariffs. He further illustrated that urban councils can only raise taxes, surcharges or borrow within limits set by the minister. Lack of fiscal autonomy on the part of the municipality greatly compromises the final outcomes with regard to service delivery. The UCA section 314 notes that the Minister may reverse, suspend and rescind resolutions and decisions of the municipality. This scenario greatly undermines tariff charges agreed upon by the municipality and its residents. This is 
because the Minister is the one with the final say on the charges and some decisions of the council can be set aside.

A key informant in the municipality complained that the municipality is not using a cost recovery system in billing and this has resulted in the council failing to recover costs incurred. This concurs with the view of Marumahoko (2011:38) who argues that limited financial autonomy explains obsolete infrastructure and poor service delivery in most urban councils. The overall dilapidation is characterised by poor road networks, inadequate water supply and poor refuse collection. Limited fiscal space on the part of the municipality inevitably leads to poor service delivery. In addition, responsiveness to residents' demands and needs which is an important attribute of good governance will also be compromised in the process.

\section{Appointment of Commissions, Top Management and Special Interest Councillors}

The MLGPWNH has also been heavily criticised for appointing top management, commissions and dismissing elected councillors replacing them with special interest councillors. Jonga and Chirisa (2009:177) contend that a majority of the selected commissioners lacked expertise in managing local authorities since they were appointed on patronage basis. ZESN (2008:2) notes that the operations of municipalities were paralyzed because no tangible cause has been provided and the dismissal of councillors and replacing them with commissions was prevalent in most urban areas. Resultantly, the day to day running of the municipality has been disturbed to the detriment of service delivery. Documentary search revealed that citizens now view the municipality as their own in the representative democracy sense but as an organ of the centre. This has negatively affected residents' participation, a key element in local governance.

\section{Tedious Procedures}

More so, the hierarchical nature of centre-local relations in the context of CM is associated with bureaucratic pathology and tedious procedures that hinder innovation, creativity, responsiveness and flexibility. For the municipality to raise fees and borrow money, it must seek approval from the Minister first. In addition, the MLGPWNH also approves the budgets of the municipality and according to one key informant in the department of finance the response of the Minister may take some time. However, this is not peculiar to Zimbabwe. Lewa et al cited by Devas (2005:5) postulate that in countries like Kenya, budgets can be approved after several months and in certain circumstances it could be approved towards the end of the fiscal year. The procedures stipulated are too tedious and this makes it difficult for the municipality to adapt to changes in the environment especially under inflationary conditions. This supports the views of Fjeldstad (2001) who opined that in practice the supervision of local authorities by the central government is weak and too often central control create more problems than they solve. These problems include delays, frustrations, additional costs, corruption and pervasive behaviour leading to poor service delivery. Edwards (1980) argues that, "there are too many agencies, doing too many things, overlapping too often, coordinating too rarely, wasting too much money and doing too little to solve real problems." This is also the situation in CM where the municipality is required to report to the MLGPWNH, Provincial Administrator, District Administrator and also to the 


\section{Macrothink Institute ${ }^{\mathrm{TM}}$}

President's office. To improve service delivery in the municipality the procedures and processes must be more flexible and speedy to enhance responsiveness to the demands of the electorates.

\section{The Stifling of Residents Participation in Municipal Operations}

High ministerial intervention affects the level of residents' participation, consultation and creativity in the municipality to the detriment of service delivery. Freeing the municipality from excessive ministerial control provides the opportunity for wider resident participation, innovation, adaptation, creativity, responsiveness and increase flexibility of the municipality in an ever-changing milieu. A survey carried out revealed that the level of ministerial influence in $\mathrm{CM}$ is high. Respondents felt that high ministerial influence was stifling residents' participation, councillors' freedom, level of consultation, creativity and innovativeness in council decision making as illustrated in the diagram below.

\section{Figure 4.2 Participation levels in Municipal Operations}

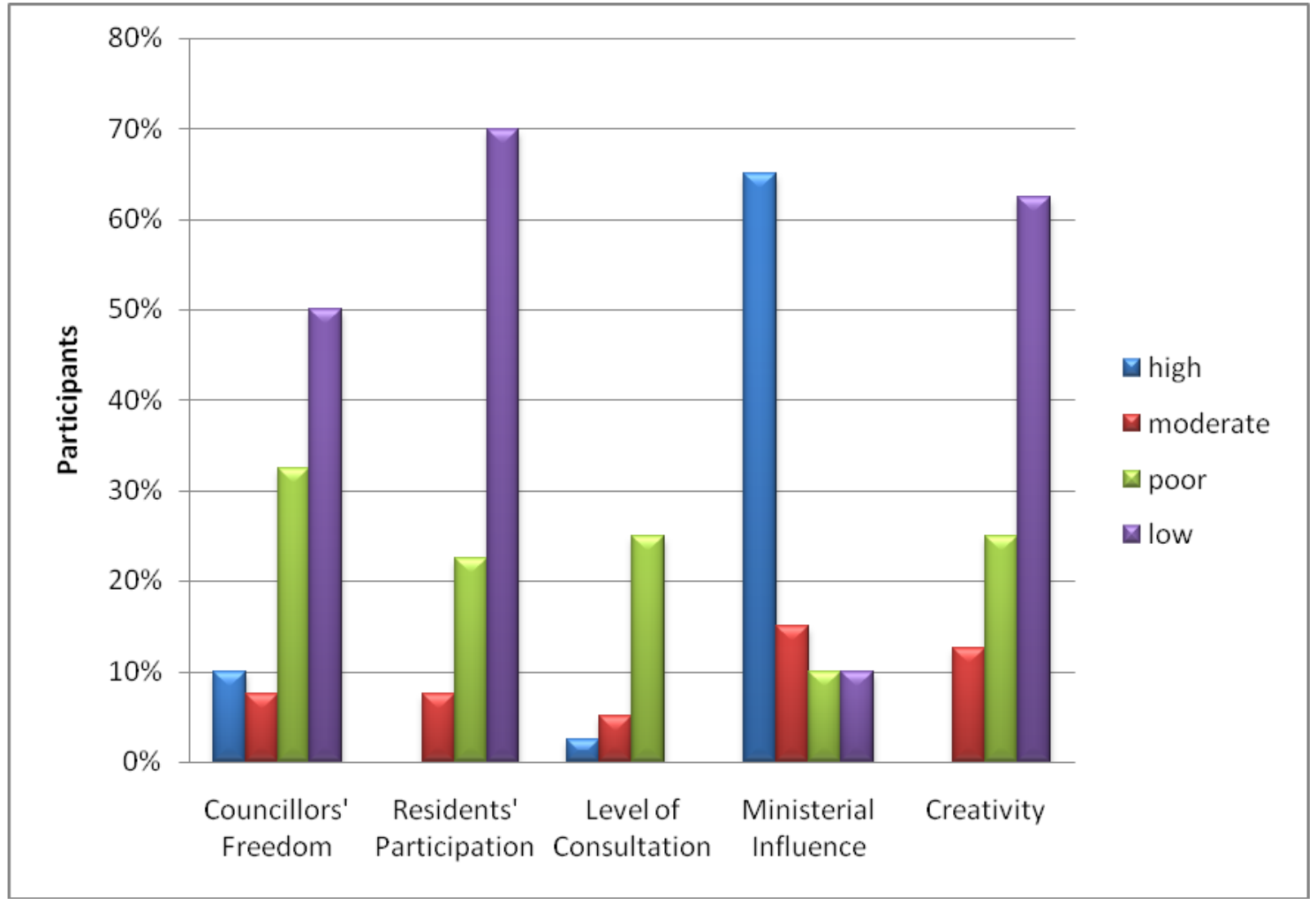

In response to the question on the level of ministerial influence in council affairs, $65 \%$ of the respondents felt that the level of ministerial interference was very high as opposed to $10 \%$ who illustrated that the level is low. On the issue of councillors' freedom, 50\% were of the view that it is low whilst $10 \%$ regarded it as high, $7.5 \%$ indicated that its moderate and $32.5 \%$ shows that it's poor. On residents' participation, $70 \%$ felt that its low, $22.5 \%$ indicated that it's poor and $7.5 \%$ regarded it to be moderate. About $62.5 \%$ of the respondents felt that encouragement of initiative in the municipality is low with $12 \%$ viewing it as moderate and 


\section{MIN Macrothink}

Journal of Public Administration and Governance

ISSN 2161-7104

2015, Vol. 5, No. 2

$25 \%$ indicated that it's poor. The level of consultation was regarded by $67.5 \%$ of the respondents to be low, $2.5 \%$ illustrated that its high, while $25 \%$ were of the view that its poor and $15 \%$ indicated that its moderate. As illustrated above, high ministerial influence in the operations of the municipality has directly affected the freedom of councillors, citizen participation, encouragement of initiative and level of consultation. Most important decisions in $\mathrm{CM}$ emanate from the Minister as directives and this leaves no room for councillors and other stakeholders to participate in decision-making processes. The low level of councillors' freedom may be as a result of the fact that the municipality is dominated by councillors from the MDC part yet the Minister is from the ZANU (PF) wing.

\section{Central Government Silence on the Qualification of Councillors}

Councillors as elected representative of the people in the locality are supposed to meaningfully participate in the committees and various council meetings. It is of paramount importance that councillors must have academic and professional qualifications for them to spear head development of the municipality. Malin (2007:134) has illustrated that the value may come from different facets like appropriate professional background, work experience, functional specialism and the ability to have insights into the issues discussed in the board and to ask searching questions. However, the UCA is silent in as far as the minimum expected qualifications of councillors are concerned. The Act does not deter those individuals with mediocre qualifications to contest as councillors. Such a scenario greatly affects service delivery. This was supported by Mutema (2012:2087) who argues that low qualifications on the part of councillors stifle councillors' ability to meaningfully participate in council meetings. The situation results in unproductive councils that lack the capacity to adjudicate critical tactical policy issues to the detriment of service delivery. Resultantly, councils end up rubber stamping the decisions of top management and those of their respective parties without proffering informed robust discussions.

Poor educational qualifications of councillors create mistrust between councillors and the Minister as the minister will tend to underrate the capacity of the academically challenged councillors to run the municipality. Resultantly, the Minister maintains a close oversight role on the operations of the municipality through directives and interventions. This results in the Minister playing an active role in the decision making process of the CM. The survey carried out supports this view. The survey revealed that the Minister plays an influential role in the decision making process followed by the town clerk and there was little demonstration that the councillors played an influential role as diagrammatically presented below. 
Figure 4.3 Decision-Making in Chitungwiza

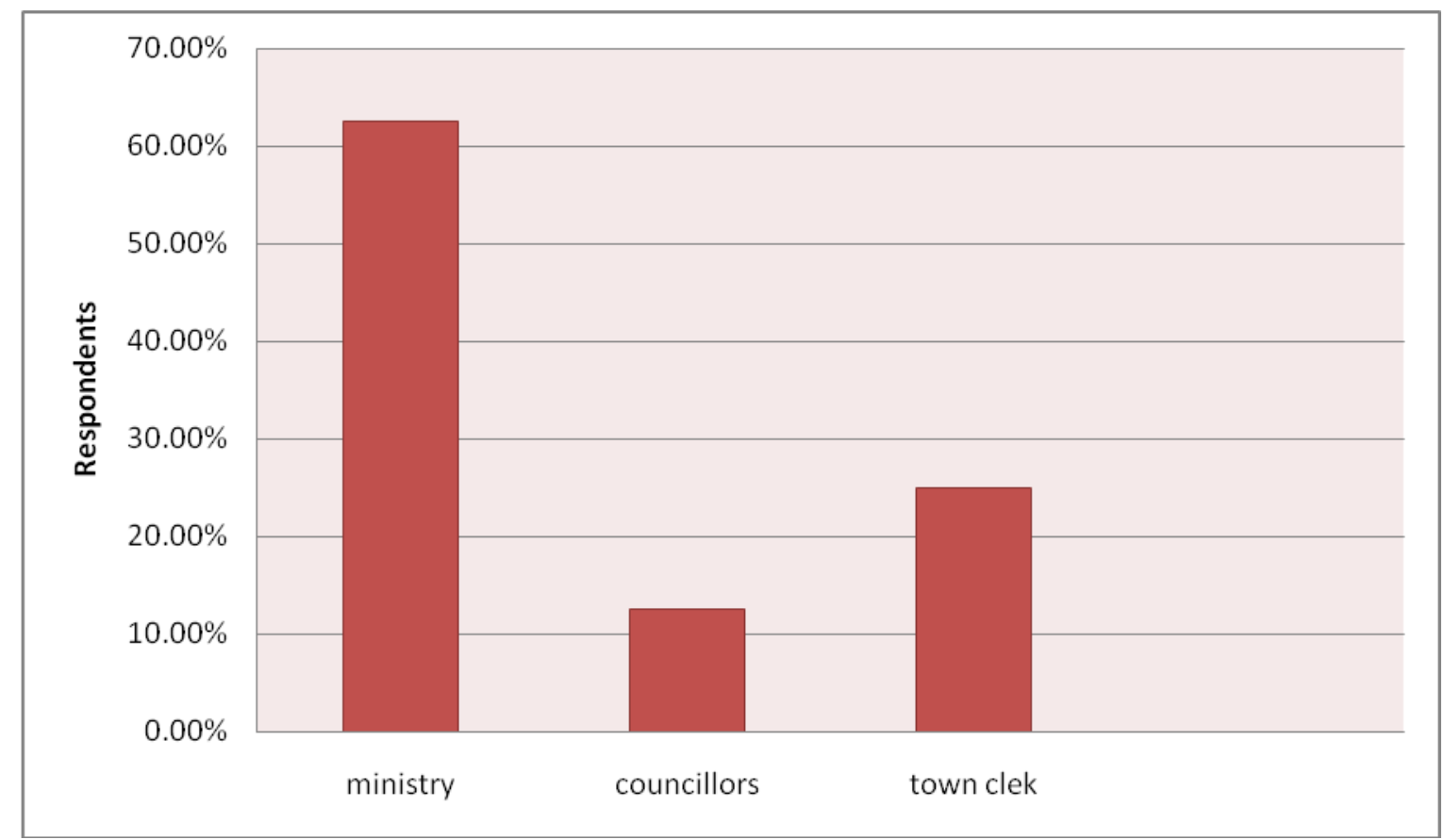

The above diagram shows that $62.5 \%$ of the respondents were of the view that the minister of local government plays an active role in the decision making process and only $12.5 \%$ of the respondents were arguing that elected councillors play an active role. Considering the fact that top council officials are appointed by the Minister it can be argued that the interests of the central government dominate in the running of the municipality. This shows that in most cases the councillors are playing a mere rubber stamping role. Therefore, centre-local relations between the parent ministry and the CM can best be explained as a master-servant relationship with the parent ministry being the master and the municipality being the servant. The municipality has become a mere appendage of the centre. Such a scenario is detrimental to effective and efficient service delivery and greatly undermines the rationale behind decentralisation. However, key informants from the DA's office and the MLGPWNH revealed that the municipality cannot be left operating on its own. They were of the view that giving the municipality much autonomy will result in rampant corruption, misappropriation of funds negation of service delivery. They advocated for an active role of the MOLG in the daily activities of the municipality to avoid such cases.

\subsubsection{Positive Implications}

\section{Reduction of Corruption}

Top officials in the MLGPWNH supported central control of municipalities citing issues of rampant corruption and misuse of funds. They argue that local authorities cannot be left on their own giving evidence of cases of corruption and misuse of taxpayers' money in Chitungwiza municipality. Documentary search revealed that corruption is rampant and 
footloose in Chitungwiza municipality (Mukonza 2013:45). Cases of corruption in Chitungwiza municipality include illegal selling and allocation of stands. In-depth interviews with residents illustrated that stands were sold and allocated in a way riddled with corruption without following the waiting list. Members of CHIRRA were of the view that top management in the municipality award themselves high salaries and allowances at the expense of service delivery. They were calling for an active role of the central government in monitoring and supervising the activities of the municipality to avoid corruption and misuse of public monies. Documentary search revealed that the centre should safeguard all public monies collected at various levels of government. Devas (2005:4) postulates that, "Indeed the distinction between 'central government money' and 'local government money' is quite arbitrary: all public money is contributed by tax payers, and it is a matter of administrative convenience which level of government collect which revenue." Implied is that the MLGPWNH must play an important role in making sure that ratepayers' funds are used for the intended purpose. In this case centre-local relation is important in as far as service delivery is concerned.

\section{Minimisation of Inter-regional Inequalities}

Centre-local relations are of supreme importance in the avoidance of inter-regional inequalities. Miller (2002:7) opines that giving local authorities autonomy may lead to an increase in inter-regional inequalities and thus widen intra-national poverty gaps and poster politically destabilizing forces if local governments. Key informants in the MLGPWNH revealed that centre-local relations ensure unbiased allocation of national resources amongst municipalities with unlike resource capacities. Different regions are differently endowed in terms of natural resources, level of economic activities, and land value, some local authorities will generate more revenue than others and afford their citizens more or better quality services than is provided in poorer jurisdictions (ibid). The need for fairness and equality in the distribution of scarce resources through the national budget justifies the importance of centre local relations in local governance.

\subsection{Dilapidated State of Service Delivery in Chitungwiza}

The municipality is struggling to provide basic goods and services to the residents. According to Madzivanyika (2011:14) "Basic services must, be available, accessible, culturally acceptable, and affordable, of good quality and provided on a non-discriminatory basis." However, the situation in Chitungwiza shows the opposite as residents have witnessed a plethora of service delivery problems such as erratic water supplies, accumulation of uncollected refuse, potholed roads and bursting sewer pipes.

Observations carried out revealed that the road network in CM is in a horrendous state. This concurs with the findings of the Parliamentary Report (2010:26) which revealed that the roads in Chitungwiza are characterised with potholes that had developed into small ponds, making roads impassable and some areas inaccessible especially during the rainy season. There is also accumulation of garbage and refuse at undesignated areas in the municipal area. The uncollected garbage had become breeding place for flies and mosquitoes and are sources of airborne diseases thus creating a health hazard (ibid). Residents in Chitungwiza were 


\section{Al Macrothink}

complaining about erratic supply of water by the municipality. The study revealed that the municipality is struggling to ensure 24 hour supply of water. This concurs with the view of Young (2006:6) who revealed that in many developing countries, the provision of water is unsatisfactory. In-depth interviews with residents revealed that residents have resorted to unprotected wells as a coping measure to the water problem. Respondents to the questionnaires showed dissatisfaction with the state of service delivery in CM as illustrated in the table below.

\section{Water Provision}

Inquiries from the residents and members of residents' associations revealed that the municipality is struggling to ensure regular supply of water. A survey conducted reviewed that Chitungwiza residents receive water supplies erratically. Respondents from the survey perceived the supplied water to be of poor quality. They complained that sometimes the supplied water has some odours, sometimes contains visible substances and can be dark in colour. In-depth interview with residents established that residents in Chitungwiza have resorted to wells which are unprotected as a coping measure to the water problem. Observations carried out demonstrated that some residents have installed water tanks at their respective homes while others use boreholes sunk by UNICEF. One key informant in the department of health illustrated that between the period July 2012 and June 2013 around 690 cases of typhoid were recorded with two cases of death. In-depth interviews with residents associations revealed that the MLGPWNH should intervene to avoid another outbreak of cholera since the municipality is struggling to provide adequate water.

\section{Waste Management}

Residents interviewed in the survey complained that refuse collection by the municipality is inconsistent. When asked on the reliability of refuse collection $10 \%$ were of the view that refuse collection is reliable, $32.5 \%$ note that it is somehow reliable, $40 \%$ regarded it as not reliable and $17.5 \%$ of the respondents view it as extremely reliable as illustrated in the table below. 


\section{Figure 4.4 Reliability of Refuse Collection}

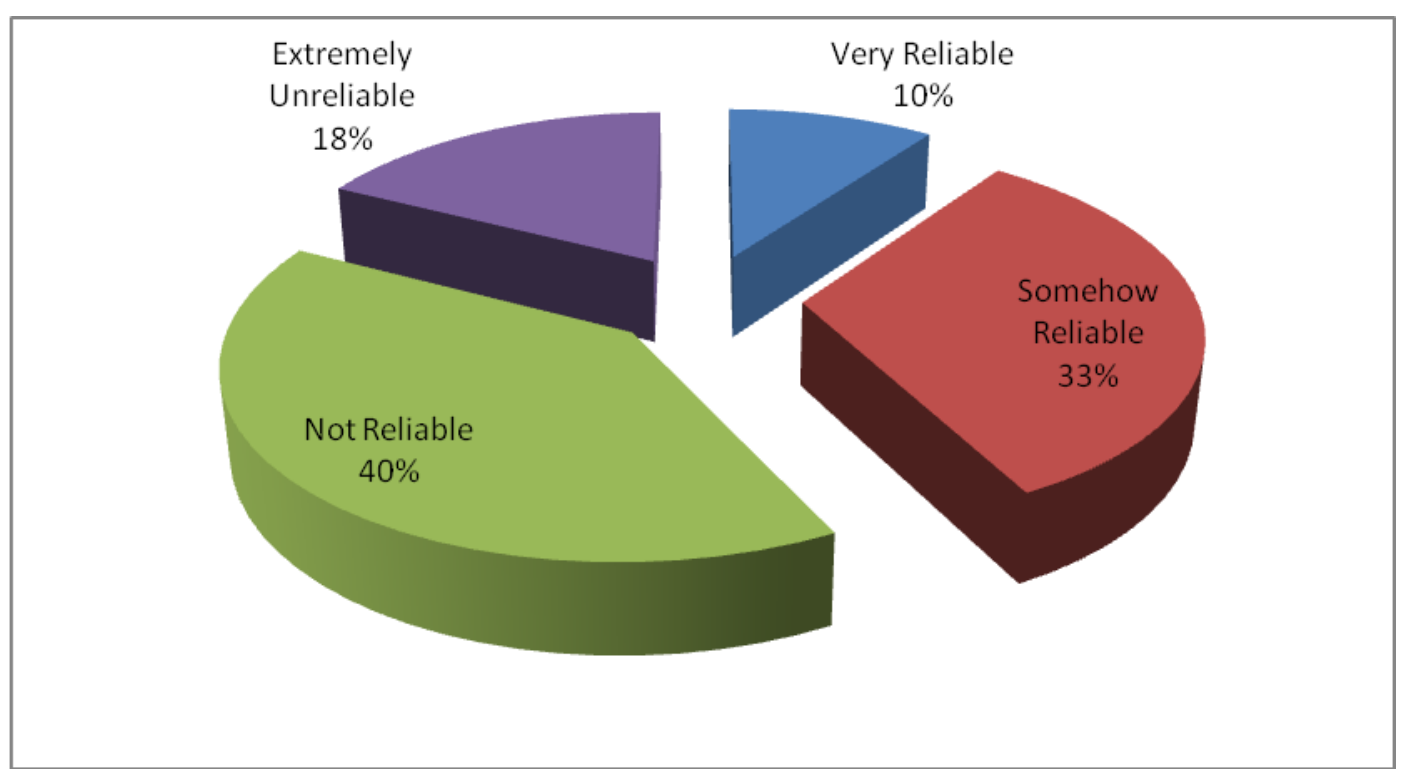

\section{Source: Fieldwork}

The chairperson of the CHIRRA illustrated that residents were paying for refuse every month but the municipality is not playing its part in as far as refuse collection is concerned. Residents in various places of Chitungwiza were complaining of heaps of garbage at street corners and other public places. Photos that were captured during observations show widespread dumping places in Chitungwiza.

\section{Undesignated Dumping Cites}

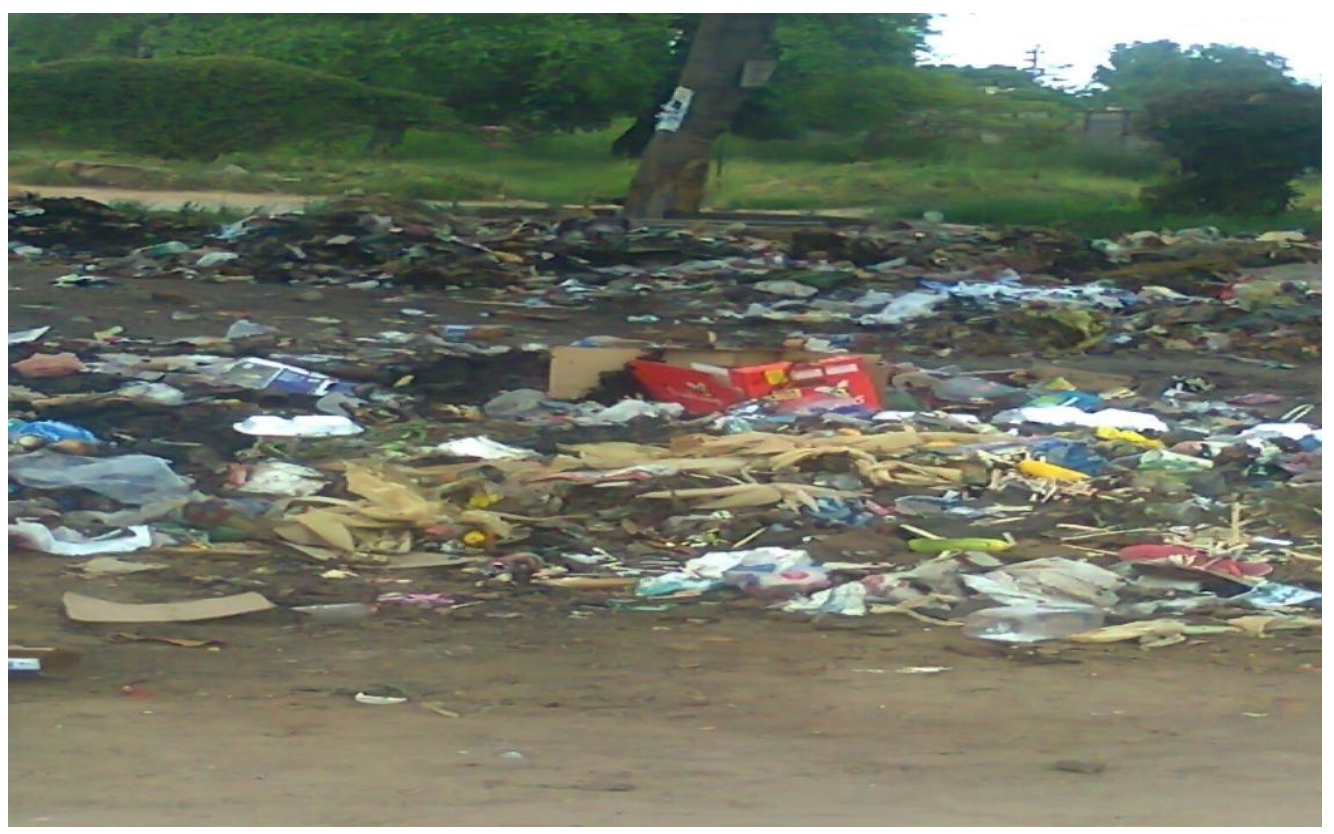

Source: Fieldwork 
The director of works illustrated that the municipality is involved in wastewater collection which is handled through sewerage systems. The municipal engineers pointed out that the municipality is facing challenges in as far as sewerage maintenance is concerned. They pointed to the issue of aging infrastructure as a major problem leading to continuous bursting of sewer pipes. An official in the department of works opined that, "the sewer system in place is too old and was designed to cater for a small population, it cannot sustain the current population which is standing at around 1000000 ." When asked on the reliability of sewerage maintenance by the municipality, $27.5 \%$ regarded it as somehow reliable whilst $30 \%$ noted that it is not reliable and 42.5 were of the view that it's extremely unreliable.

\section{Transportation Systems Management}

The CHIRRA chairperson was dissatisfied with the way the municipality was fulfilling its mandate of making sure that access to all parts of the community is ensured. He illustrated that road maintenance in Chitungwiza leaves a lot to be desired, the roads linking various places (residential and industrial) within the municipality are characterised with potholes. In general, residents illustrated that they were not satisfied with the overall state of service delivery.

\section{Conclusions and Recommendations}

\subsection{Conclusions}

From the foregoing analysis, it can be drawn that centre-local relations between the MLGPWNH and the CM are hyper-centralised. The parent ministry retains overall powers and control over the municipality. Over the years, the municipality continued to depend heavily on the MLGPWNH for most of its operations and general sustenance rather than becoming a relatively autonomous organisation. The Minister who is supposed to play a strategic role in policy formulation and implementation is involved in the day to day running of the municipality leaving no room for elected councillors and residents in general to determine their own destiny. Findings indicated that the centre-local relationship that is suppose to foster independence and autonomy of the municipality in the provision of goods and services has turned into a master-servant relationship that has negatively affected service delivery in CM. The Minister is meddling in the affairs of the municipality through manipulation of the UCA, issuing directives and dismissing elected councillors replacing them with commissions and special interest councillors to the detriment of service delivery.

Ministerial interference in the management of the CM has negatively impacted service delivery. Effective service delivery is hampered by a high level of ministerial interference in the decisions of the municipality. Some ministerial directives for instance the ordering of the municipality by the Minister to pay high salaries and allowances to commissions and investigation teams have milked the cash-strapped municipality of the much needed money for service delivery. Such directives left the municipality bankrupt to the detriment of service delivery. High ministerial interference explains obsolete infrastructure and poor service delivery to ratepayers that characterise Chitungwiza.

Service delivery in $\mathrm{CM}$ is in a dilapidated state. Residents have witnessed a plethora of 
service delivery problems like erratic water supplies, accumulation of uncollected refuse, potholed roads, poor health provision, inadequate housing and bursting sewer pipes. The road network in the municipality is in a horrendous state because the roads are heavily potholed creating a nightmare for motorists. There is also accumulation of garbage and refuse at undesignated areas in the municipal area. The uncollected garbage has developed into reproduction grounds for flies and mosquitoes and in the process creating health risk for residents. Residents in Chitungwiza were complaining about erratic supply of water by the municipality. The municipality is also struggling to ensure adequate supply of water. Residents have been forced to use unprotected sources of water as a measure of dealing with water challenges. The scenario has resulted in cholera and diarrhoea outbreaks claiming lives of people.

\subsection{Recommendations}

The study recommends that the MLGPWNH must create a favourable environment for stakeholder participation in the operation of municipalities. This is in line with the view of Olowu (2009) who advocated for collective decision making. He argues that a substantial number of residents within local authorities must be involved in formulating the rules services needed within their respective municipalities. This concurs with the view of IDAZIM (2010:59) that it is important that during any reconstruction process local authorities and residents are encouraged on all fronts to connect. Service delivery or infrastructure investment priorities should be developed in concert with communities and their representatives (Ibid). The budget process for instance must be participatory to ensure that available finances are linked to the demands of the people. In CM provisions for residents' involvement in the business of the municipality are very weak. This greatly undermines effective service delivery. Therefore, residents must be seriously engaged in matters impacting them in their living for instance water provision, health provision, sewerage maintenance and housing provision.

The study also recommends the need for meaningful devolution such that the central government can give local governments more autonomy. The municipality must function as an autonomous organisation and the parent ministry must cease interfering in the business of the municipality. As has been illustrated elsewhere, in the case of South Africa, local authorities are treated as distinctive spheres of government and the distinctive elements reflects that municipalities exist in their own right and is the final decision-maker on a defined range of functions (Layman (2003), Scheidegger (2008)). This scenario greatly improved service delivery and protected local authorities from uncalled for central government interference. The Zimbabwean local government system is hyper-centralised with the Minister having excessive powers. Thus, there is need to revise the UCA and align it with the Zimbabwean Constitution Amendment No. 20 Act 2013. The MLGPWNH must strive to make sure that devolution is fully implemented. Marumahoko (2011:38) argues that the lack of adequate fiscal autonomy explains not only the obsolete infrastructure that characterises urban areas but also the poor delivery of social goods and services to ratepayers. Freeing the municipality will enhance wider citizen participation, innovation, adaptation, responsiveness and increase flexibility of the municipality in an ever changing environment. 


\section{Macrothink}

Journal of Public Administration and Governance ISSN 2161-7104

This recommendation is in line with Young (1996:161) who stresses that local government could play a greater role if allowed more autonomy and regular, independent sources of revenue.

In line with the principal-agent theory, the introduction of objective and systematic performance management will go a long way in improving service delivery. According to Waterman and Meier (1998:176) the principal-agent theory recommends that given information asymmetry the principal (MLGPWNH) must control the agent (Chitungwiza municipality) to achieve the intended goals. Implied is that the MLGPWNH must design incentive structures to monitor the performance of the municipality. The performance management system in the country is too political and is mainly determined by the minister to the detriment of service delivery. This has resulted in biased dismissals of councillors and mayors in the municipality. A balance score card must be used to measure the performance of mayors, councillors, top council officials and even the minister. Effective implementation of performance management will help improve the performance of various stakeholders in the management of local authorities. After managing performance, good performers must be rewarded and non-performers must be sanctioned accordingly.

The MLGPWNH must introduce capacity building programmes for councillors, mayors and other council employees. The centre must introduce training programmes in policy formulation, implementation and analysis such that councillors and mayors can make informed contributions to the development of municipalities. This recommendation is also supported by the Zimbabwe Institute (2005:20) which revealed that the central government must introduce a policy which insists on the training of councillors on the value and importance of shared leadership and general qualities of a good and effective leader. The study revealed that most councillors and mayors lack knowledge and competences in the field of local government management. Therefore the introduction of training programmes for councillors will help improve their participation in council affairs and may result in improved service delivery. IDAZIM (2010:59) postulates that local councillors badly need training in the skills necessary to work effectively in the council.

\section{Reference}

Bevir, M. 2009. Key Concepts in Governance: Centre-Local relations. London: SAGE Publications.

Caers, R. 2006. Principal-agent Relationship on the Stewardship-agency Axis. Nonprofit Management and Leadership. Vol 7(1) 25-47

Chandler, J.A. 1993. Local Government in Liberal Democracies: An Introductory Survey. New York: Routledge.

Coletta, D. 2013. Principal-agent theory in Complex Operations, Small Wars and Insurgencies. Vol 24(2) 306-321.

Devas, N 2005. The Challenges of Decentralisation. London: University Press. 


\section{Macrothink}

Journal of Public Administration and Governance ISSN 2161-7104 2015, Vol. 5, No. 2

Dipholo, K and Gumede, N. 2013. A Comparative Analysis of Intergovernmental Relations in Botswana and South Africa: The Dynamics of a Two-tier System versus a Three-tier System. The Journal of African and Asian Local Government Studies. Vol 2 No 1

Economic Consulting Associates. 2011. Zimbabwe Urban Water Tariff Study. Final Report

Edwards, G.C. 1980. Implementing Public Policy. Washington DC: Quarterly Press

Fjeldstad O-H. 2001. Taxation, Coercion and Donors: Local Government Tax Enforcement in Tanzania. Journal of Modern African Studies. 39(2): 289-306.

Golola, L. M., 2003, 'Decentralization, Local Bureaucracies and Service Delivery in Uganda', in Reforming Africa's Institutions. New York: United Nations University Press.

Helmsing, H. H. 1995. Decentralisation Policy in Zimbabwe: Impact on Local Government Performance. Harare: Institute of Development Studies.

Helmsing, H.H. 1990. "Transforming Rural Local Government, Zimbabwe Post Independence Experience"

IDAZIM. 2010. Local Governance in Transition: Zimbabwe's Local Authorities during the Inclusive Government. Online on www.rti.org/pubs/zimbabwelocalgovernance. Date accessed 05/01/2014

Makumbe, J. 1998. Participatory Development: The Case of Zimbabwe. Human Rights Bulletin. 21-25

Meckling, W. 1976. Theory of the Firm: Managerial Behavior, Agency Costs, and Ownership Structure. Journal of Financial Economics, 3: 305-360.

Jonga, W. 2012. Prioritizing Political Banditry than Good Governance: Rethinking Urban Governance in Zimbabwe. Addis Ababa: Ethiopian Civil Service University.

Jonga, W and Chirisa, I. 2009. Urban Local Government in Crucible: Empirical Overtones Of Central Government Meddling In Local Urban Councils Affairs In Zimbabwe. Harare: University Press.

Machingauta, N. 2010. Local government reform in Zimbabwe: A Policy Dialogue. Western Cape: University of Western Cape.

Madzivanyika, L. 2011. The Impact of Weaknesses in the Urban Councils Act on Efficient and Effective Service Delivery in Urban Local Councils in Zimbabwe. [Online]. Available: www.mlgi.org.za/...local-government/service-delivery-in-urban-local...

Makumbe, J. 1998. Participatory Development: The Case of Zimbabwe. Human Rights Bulletin, 21-25

Marumahoko, S. 2011. Fiscal Autonomy of Urban Councils in Zimbabwe: A critical Analysis. Law, Democracy and Development Vol.15. Available: www.ajol.info/index.php/ldd/article/view/72715 


\section{Macrothink}

Journal of Public Administration and Governance ISSN 2161-7104 2015, Vol. 5, No. 2

Meckling, W. 1976. 'Theory of the Firm: Managerial Behaviour, Agency Costs and Ownership Structure', Journal of Financial Economics, Vol.3, 305-360.

Miller, K.L 2002. Advantages and Disadvantages of Local Government Decentralisation. A Presentation to the Caribbean Conference on Local Government Decentralisation. June 25 to 28

Mukonza, M.R. 2013. Anti-corruption and Local Governance in Zimbabwe: A Case Study of Chitungwiza Municipality. Journal of US-China Public Administration, Vol 10(1), 39-48

Mushamba, N. 2010. Local government reform in Zimbabwe: A Policy Dialogue. Western Cape: University of Western Cape.

Mutema, P.E. 2012. Debating the Impact of the Urban Councils Act Chapter 29.15 (1996) on the Practice of Good Corporate Governance in Zimbabwe Urban Local Authorities. International Journal of Asian Science 2(11): 2084-2095

Nhema, Alfred G. 2002. Democracy in Zimbabwe: from liberation to liberalization. Harare: University of Zimbabwe Publications.

Olowu, D. 2009. Decentralization and Local Government in the Zimbabwean Constitution. [Online]. Available: tsime.uz.ac.zw/.../WmltX09sb3d1X0R1Y2VudHJhbGl6YXRpb24uZ

Urban Councils Act Chapter 29:15

Scheidegger Ursula, How to male democracy work? Local government, the beneficial and destructive potential of social capital in post-apartheid South Africa in Nhema, Alfred G. and Paul Tiyambe Zeleza (eds.) 2008. The Resolution of African Conflicts: the Management of Conflict Resolution and Post-Conflict Reconstruction. James Currey, Oxford and Ohio University Press, Athens.

Waterman, R. W and Meier, K. J. 1998. Principal-agent Theory: An Expansion. Journal of Public Administration Research and Theory Vol 8(2) 173-202

Zhou, G. And Madhekeni, A. 2012. Legal and Institutional Framework: The 'Achilles Heel' Of Local Authorities and Raison D'etre of Ministerial Intervention in Zimbabwe. Public Administration and Governance Vol. 2 No.3

\section{Newspapers}

Chipangura, T. 2014. Chombo Actions Aid Plunder of Cities. The Standard, 9-15 February, 11 Matenga, M. 2013. Chitown Probe Team Gobbles \$15 000 daily. News Day 15 November

Sibanda, N. 2013. Chombo Robbing Town to pay for Mistakes, Says Residents. Free and Fair Zimbabwe Elections, 22 November

Tafirenyika, M. 2013. Debt Write-off. Chitungwiza Water Crisis Deepens. Daily News, 16 August. 